\title{
Ethics matters: the integration of ethical considerations in management accounting textbooks
}

\author{
Berend van der Kolk \\ Department of Accounting \& Management Control, IE Business School, IE University, Madrid, Spain
}

\begin{abstract}
This paper examines the integration of ethical considerations in management accounting (MA) education. Drawing on the work of Alisdair Maclntyre, it is argued that MA instruments such as performance measurement are not morally neutral, but instead bear moral implications. Therefore, this paper contends that MA students should be trained to take these moral implications into consideration alongside MA's technical aspects. A content analysis is carried out to examine the integration of ethical considerations in top-ranked MA textbooks. The findings indicate that these textbooks, particularly the introductory textbooks, marginally integrate ethical considerations. Furthermore, the findings point to the risk of detaching ethical considerations from the discussion of MA's technical aspects, which may weaken the potential of the ethical considerations and turn them into 'afterthoughts'. Finally, this paper offers practical suggestions for the improvement of the integration of ethical considerations in MA education and concludes with directions for future research.
\end{abstract}

ARTICLE HISTORY

Received 28 June 2018

Revised 11 September 2018

Accepted 12 October 2018

\section{KEYWORDS}

Ethics; Maclntyre; management accounting; morality; textbook

\section{Introduction}

Although the ethics of financial accounting education has been the object of public and academic attention for some time (e.g. Amernic \& Craig, 2004; Chabrak \& Craig, 2013; Cooper, Dacin, \& Palmer, 2013; Graham, 2012; Murphy \& O’Connell, 2017), it looks as if management accounting (MA) education escapes similar scrutiny (cf. Sikka, Haslam, Kyriacou, \& Agrizzi, 2007). The relative absence of attention for ethics in MA education is striking because a growing stream of literature suggests that MA instruments do not only yield 'desirable' effects such as improved performance, but can also result in unethical behavior and other undesirable outcomes (cf. Cugueró-Escofet \& Rosanas, 2017; FrancoSantos, Lucianetti, \& Bourne, 2012; Rosanas \& Velilla, 2005). For instance, an excessive focus on performance targets 'may have prompted the risk-taking behavior that lies at the root of many real-world disasters' (Ordóñez, Schweitzer, Galinsky, \& Bazerman, 2009, p. 9), and international transfer pricing enables the large-scale avoidance of taxes by multinationals, giving rise to potential physical, economic and psychological harm (Mehafdi, 2000; Sikka et al., 2007). Given these potentially harmful consequences, it seems appropriate that MA students learn to ask questions such as 'What are the 
ethical risks and consequences of using performance targets?' and 'Do I think it is ethically acceptable to use international transfer pricing constructions to avoid paying taxes in developing countries?' This paper aims to bring such ethical considerations in MA education under the attention of educators, researchers, practitioners and students by arguing that MA instruments are not 'mere technical tools' but that they are 'morally laden'. Furthermore, the content of top-ranked MA textbooks will be assessed and suggestions will be provided as guidance for improving the balance between the 'ethical' and the 'technical' aspects in MA education.

The contribution of this paper to the field of accounting education is twofold. First, this paper develops an argument for the stronger integration of ethical considerations in MA education, drawing on the work of Alisdair MacIntyre (1981). MacIntyre (1981) critically discussed managerial actions and argued that these are not 'morally neutral', but rather have an inherent ethical dimension. Second, this paper examines top-ranked MA textbooks and proposes ways in which ethical considerations can be further integrated in MA education. By doing so, this paper extends the body of research that critically examines the (lack of) integration of ethics in accounting education (Amernic \& Craig, 2004; Boyce, 2004; Carmona, 2013; Chabrak \& Craig, 2013; Graham, 2012; Young \& Annisette, 2009), and continues constructively by offering practical suggestions for authors of MA textbooks and MA teachers.

The following section lays out an argument in favor of integrating ethical considerations in MA education, and explores what already has been done to integrate ethical considerations in accounting education in general. The third section deals with the method used to carry out a content analysis of top-ranked MA textbooks, and the fourth section contains the findings of this analysis. Subsequently, some suggestions are made for improving the integration of ethical considerations in MA education. The final section concludes with the main implications of this paper, its limitations and suggestions for further research.

\section{Background}

\section{Maclntyre and acclaimed moral neutrality}

To argue why it is important to include ethical considerations in MA education, I want to start by drawing on an analysis of 'the manager' by the British moral philosopher Alisdair MacIntyre. In After Virtue, MacIntyre (1981) critically examines the character of managers and management as a discipline. According to MacIntyre, managers and writers about management are at best unaware, and at worst ignorant, of the inherent ethical dimension of managerial work. MacIntyre calls such such managers 'hollow' and criticizes them for being mainly concerned with 'technique' and 'effectiveness'.

Managers themselves and most writers about management conceive of themselves as morally neutral characters whose skills enable them to devise the most efficient means of achieving whatever end is proposed. (MacIntyre, 1981, p. 74, emphasis added)

MacIntyre argues, however, that this perception of managerial activities as morally neutral is misleading. He sees managers as people who provide a culture with definitions of what is morally acceptable by playing their social role. For MacIntyre, managerial work is in 
essence about the 'manipulation of human beings into compliant patterns of behavior' (MacIntyre, 1981, p. 74). MacIntyre argues that by carrying out this social role, the manager 'defines' that - for her or him - it is morally acceptable to limit the autonomy of others. The role of managers is thus morally laden. Even without actively participating in moral debates or being aware of this role as moral characters, managers define what is morally acceptable. In other words, managerial actions are not 'morally neutral', although managers themselves do not seem to often reflect on this moral dimension of their work, and may continue to see themselves as 'uncontested figures' (MacIntyre, 1981, p. 30) or 'amoral technicians' (Beabout, 2013, p. 103).

Furthermore, the possible effects of MA instruments form another important reason to ethically reflect on the use of MA instruments. This point can be illustrated by examining the use of performance measurement systems. Performance measurement systems are often designed to serve a specific 'end', such as increasing efficiency, enhancing performance or empowering employees (cf. Franco-Santos et al., 2012), however, they can also perhaps even simultaneously - decrease intrinsic motivation (Frey, Homberg, \& Osterloh, 2013), prevent learning or trigger short-termism and cheating behavior (cf. Ordóñez et al., 2009). Giving one end priority over another end or effect can only be done by prioritizing one value over another value: the values someone holds will inform the choice for a specific end. Since an MA instrument can serve a specific, selectable 'end' while ignoring or even harming another end, its use or application is 'morally laden', because 'questions of ends are questions of values' (MacIntyre, 1981, p. 26). Therefore, it is important that the MA student acknowledges that MA instruments have moral implications, and that the student is trained to thoughtfully consider whether, and if so, how, to make use of an MA instrument in a particular situation. Challenging and questioning the underlying values of MA instruments and their effects should thus be an integrated part of MA education.

The following section continues by discussing what has been done in the literature to integrate ethical considerations in accounting education in general.

\section{The 'technical' and the "ethical' aspects of accounting education}

Although there have been various initiatives that aimed to bring in more ethical reflections in accounting education - such as learning 'outside the circle' to transcend disciplinary boundaries (Boyce, 2004), using literature (Young \& Annisette, 2009) and media texts (Kaidonis, 2004) to reflect on the ethics of accounting - such initiatives have generally been evaluated as 'rather unsuccessful' (Carmona, 2013, p. 113) and 'sticking plasters to remedy heart failure' (Hopper, 2013, p. 128). The 'technical' aspect of accounting education - that deals with questions such as 'How do budgets or incentives function?' and 'Which accounting decision results in the highest net returns?' - has remained dominant, and not much has really changed this dominance in the past 100 years of accounting education (Merino, 2006). The 'technical' aspect of MA education resembles what Hopper, Storey, and Willmott (1987, p. 438) called 'conventional management accounting knowledge' and what Boyce (2008, p. 264) referred to as 'vocational' (as opposed to humanistic) aspects of education. The 'inertia' of accounting education has resulted in a plethora of critique on accounting education. For instance, it has been criticized as 'constrained within narrowly defined, but mis-conceived, disciplinary boundaries' (Boyce, 2004, 
p. 565), and as 'colonized by positive economic science and indoctrinated by neo-classical economics' (Chabrak \& Craig, 2013, p. 101). In addition, prior research found that accounting education overemphasized the 'technical and instrumental view [... while including] little discussion of theories, principles, ethics, public interest, globalization, scandals or social responsibility' (Sikka et al., 2007, p. 3). In a similar vein, Hopper (2013, p. 128) states:

Much accounting education overly inculcates technical skills and rote, rule-based learning; neglects theory (especially other than positive economics and agency theory), ethics and morality.

In other words, there seems to be an overemphasis on the 'technical' aspects of accounting education, at the expense of the 'ethical' aspects of accounting education. Murphy and O'Connell (2017) made a similar observation and coined this the dominance of 'accounting formalism', which neglects 'the social, critical and ethical dimension' (Murphy \& O'Connell, 2017, p. 1). The dominance of the technical over the ethical aspects of accounting education have led prior research to call for the adoption of more ethical theory, dilemmas, questions and ethical considerations in accounting education (Amernic \& Craig, 2004; Boyce, 2004, 2008; Carmona, 2013; Chabrak \& Craig, 2013; Hopper, 2013; Merino, 2006; Murphy \& O’Connell, 2017; Saravanamuthu \& Tinker, 2002, 2008; Sikka et al., 2007). Much is yet to be done, however, especially in the field of MA, as the majority of the above-mentioned papers seem to address other fields of accounting than MA, as noted by Sikka et al. (2007, p. 13):

In the wake of scandals attention is usually focused on financial accounting and auditing practices and education but management accounting seems to escape scrutiny.

Hence, the 'ethical' aspects of MA seem to be particularly underemphasized (Amernic \& Craig, 2004; Chabrak \& Craig, 2013; Hopper, 2013; Sikka et al., 2007) and questions such as 'Is it good to use incentives in this situation?' and 'What are the potential ethical consequences of the large-scale application of performance measurement?' have not received much attention in MA education. It is the aim of this paper to extend this line of research and bring the ethical aspects of MA education under the attention of educators, researchers, practitioners and students.

The call for a broader, more balanced perspective on MA education can also be seen in a broader light of critique on the dominance of mainstream economic thought and the accompanying models of human behavior. Such critique is not only expressed by accounting scholars, but also by popular economists such as Sedláček (2011) and Raworth (2017), ${ }^{1}$ and philosophers such as Nussbaum (2010). Nussbaum (2010) devoted the book Not For Profit to her concerns with the 'technical' education that students in various degree programs receive nowadays. She discusses how various academic institutions and schools cut costs by removing education in the non-technical fields such as the humanities. Nussbaum's book can be seen as a plea for a stronger integration of ethics and the humanities in educational programs because they form a welcome complement to the more technical aspects. Nussbaum links her diagnosis of the current unbalance in education to even wider issues:

We should have no objection to good scientific and technical education, and I shall not suggest that nations should stop trying to improve in this regard. My concern is that other 
abilities, equally crucial, are at risk of getting lost in the competitive flurry, abilities crucial to the health of any democracy internally, and to the creation of a decent world culture capable of constructively addressing the world's most pressing problems. (Nussbaum, 2010, p. 7)

Nussbaum suggests that by offering an unbalanced, overly technical program to students, we might endanger the very future of democratic systems and our ability to address global problems. So, also outside of the field of accounting thinkers and academics have expressed their concerns regarding the dominance of technical aspects in education, and called for a more pronounced role for ethical considerations.

This section developed an argument in favor of integrating ethical considerations in MA education and suggested that the technical aspects of MA education are too dominant. Yet, there is currently a gap in the literature regarding the empirical evidence to support such a claim. This paper partially addresses this gap by conducting a content analysis of influential textbooks in the field of MA to provide clues regarding the balance between technical and ethical aspects in MA education.

\section{Method}

A content analysis has been identified as a powerful research technique to 'analyze data within a specific context in view of the meanings someone - a group or a culture - attributes to them' (Krippendorff, 1989, p. 403). Sampling the relevant content is important for a content analysis in order to be able to draw meaningful conclusions (Krippendorff, 1989, p. 406). To define a range of textbooks, I rely on earlier work by Hoffjan and Wömpener (2006) and Strauss and Zecher (2013), who studied the use of textbooks in the field of MA. Strauss and Zecher (2013) surveyed accounting scholars from the USA, Canada, UK, Continental Europe and Australia, and their findings indicate that five textbooks in particular are used in MA education: Merchant and Van der Stede (2007), Anthony and Govindarajan (2007), Simons (2000), Horngren, Datar, and Rajan (2015) and Zimmerman (2003). ${ }^{2}$ Although these textbooks were written at different moments in time, according to Strauss and Zecher (2013) these textbooks (and their newer editions) are still considered 'seminal works' in MA and are to date widely used in MA education. These textbooks thus form a relevant sample if we want to get an impression of the current integration of ethical considerations in MA education.

All textbooks have been scrutinized and particular attention was paid to remarks about ethics, fraud, underlying assumptions, human behavior and the ethical reflections on MA instruments. A summary report was written for each textbook, which contained the extent to which the aforementioned topics were addressed and integrated in the textbook's exercises, main text and cases. These summary reports are included in the next section and an overview of the variability of the findings is reported in Table 1. Only explicit mentions of ethics-related topics in the exercises, main text and cases are considered here. This means that, for instance, a case about how to deal with a fraud case in a small company is included in the analysis (Merchant \& Van der Stede, 2007, pp. 20-21), but a case about the sustainable clothing manufacturer Patagonia (Merchant \& Van der Stede, 2007, pp. 379-392) is not included, because the latter case did not explicitly deal with an ethical aspect of an MA instrument, and did not include explicit information or questions about morality. Furthermore, when 'technical' risks of, for instance, the use of performance measures were 
Table 1. A synopsis of the integration of ethics in top-ranked MA textbooks.

\begin{tabular}{|c|c|c|c|c|c|c|c|c|c|c|}
\hline $\begin{array}{l}\text { Author(s) \& Book } \\
\text { Title* }\end{array}$ & $\begin{array}{l}\text { Edition/ } \\
\text { year/ } \\
\text { ITR/IMD/ } \\
\text { ADV** }\end{array}$ & $\begin{array}{l}\text { Number of } \\
\text { Explicit } \\
\text { Fraud/ } \\
\text { Ethics } \\
\text { Cases }^{* * *}\end{array}$ & $\begin{array}{c}\text { Ethical } \\
\text { considerations in } \\
\text { exercises }\end{array}$ & Ethical theory & $\begin{array}{l}\text { Assessment of } \\
\text { underlying } \\
\text { assumptions on } \\
\text { human behavior } \\
\text { related to ... }\end{array}$ & $\begin{array}{c}\text { Ethics in } \\
\text { index } \\
* * * *\end{array}$ & $\begin{array}{l}\text { Fraud } \\
\text { in } \\
\text { index } \\
* * * * *\end{array}$ & $\begin{array}{l}\text { Number of } \\
\text { pages in main } \\
\text { text explicitly } \\
\text { on Fraud / } \\
\text { Ethics }{ }^{* * * * *}\end{array}$ & $\begin{array}{l}\text { Chapter } \\
\text { on ethics }\end{array}$ & $\begin{array}{l}\text { Integrated ethical } \\
\text { considerations in } \\
\text { main text }\end{array}$ \\
\hline $\begin{array}{l}\text { Anthony \& } \\
\text { Govindarajan: } \\
\text { Management } \\
\text { Control Systems }\end{array}$ & $\begin{array}{c}\text { 12th / } 2007 \text { / } \\
\text { ITR / IMD }\end{array}$ & 0 & $\begin{array}{l}\text { Not explicitly } \\
\text { addressed }\end{array}$ & No & $\begin{array}{l}\text { Agency theory } \\
(533-534)\end{array}$ & No & No & $0 \mathrm{pp}$ & No & No \\
\hline $\begin{array}{l}\text { Horngren, Datar \& } \\
\text { Rajan: Cost } \\
\text { Accounting: } \\
\text { A Managerial } \\
\text { Emphasis }\end{array}$ & $\begin{array}{c}\text { 15th / } 2015 \text { / } \\
\text { ITR / IMD }\end{array}$ & 0 & $\begin{array}{l}\text { A few, about half } \\
\text { the number of } \\
\text { chapters include } \\
\text { an ethics-related } \\
\text { sub question }\end{array}$ & No & $\begin{array}{l}\text { Budget use } \\
(218-221)\end{array}$ & Yes (3) & No & $\begin{array}{c}6 \text { pp. }(16-19, \\
220,890)\end{array}$ & No & $\begin{array}{l}\text { A few, mostly } \\
\text { limited to IMA's } \\
\text { code of conduct }\end{array}$ \\
\hline $\begin{array}{l}\text { Merchant \& } \\
\text { Van der Stede: } \\
\text { Management } \\
\text { Control Systems }\end{array}$ & $\begin{array}{r}\text { 2nd / } 2007 \text { / } \\
\text { IMD / ADV }\end{array}$ & $\begin{array}{c}14(20-21, \\
194-208, \\
216-217, \\
608-630, \\
641-648 \\
701- \\
720)\end{array}$ & $\begin{array}{l}\text { Yes, but limited and } \\
\text { often implicit }\end{array}$ & $\begin{array}{c}\text { Yes, but limited: } \\
\text { Utilitarianism, } \\
\text { Virtue ethics, Ethics } \\
\text { of duties, Ethics of } \\
\text { justice }\end{array}$ & $\begin{array}{l}\text { Motivation } \\
\quad(9-10,31-32) \\
\text { Incentives } \\
(335-340) \\
\text { Nonprofit (788) }\end{array}$ & Yes (16) & Yes (6) & $\begin{array}{l}28 \mathrm{pp} . \\
(9-10,180- \\
191 \\
685-699 \\
578-580)\end{array}$ & $\begin{array}{c}\text { Yes } \\
\text { (chapter } \\
15)\end{array}$ & $\begin{array}{l}\text { Quite some, but } \\
\text { most are located } \\
\text { in chapter } 15\end{array}$ \\
\hline $\begin{array}{l}\text { Simons: Performance } \\
\text { Measurement and } \\
\text { Control Systems for } \\
\text { Implementing } \\
\text { Strategy }\end{array}$ & $\begin{array}{l}\text { 1st / } 2000 \text { / } \\
\text { IMD / ADV }\end{array}$ & $\begin{array}{c}3(272, \\
646- \\
676)\end{array}$ & $\begin{array}{l}\text { Not explicitly } \\
\text { addressed }\end{array}$ & No & $\begin{array}{l}\text { General (12-14) } \\
\text { Intern control } \\
(298,299) \\
\text { Levers of } \\
\text { control } \\
(306-308)\end{array}$ & No & Yes (1) & $\begin{array}{l}8 \mathrm{pp} . \\
(269-273, \\
279-282)\end{array}$ & No & $\begin{array}{l}\text { A few, but mostly } \\
\text { limited to limits } \\
\text { of performance } \\
\text { measures }\end{array}$ \\
\hline $\begin{array}{l}\text { Zimmerman: } \\
\text { Accounting for } \\
\text { Decision Making } \\
\text { and Control }\end{array}$ & $\begin{array}{c}\text { 4th / } 2003 \text { / } \\
\text { ITR / IMD }\end{array}$ & 0 & $\begin{array}{l}\text { Not explicitly } \\
\text { addressed }\end{array}$ & No & $\begin{array}{l}\text { General (3-4) } \\
\text { Theory X \& Y } \\
\text { (185) } \\
\text { Agency theory } \\
(157-158)\end{array}$ & No & Yes (1) & 1 p. (16) & No & No \\
\hline
\end{tabular}

* = Ordered alphabetically, the five textbooks included here were identified by Strauss and Zecher's (2013) as the top-ranked MA textbooks.

** = Edition and publishing year of the textbook, and overall 'level' of the textbook (ITR = Introductory, IMD = Intermediate, ADV = Advanced).

*** $=$ Cases (not exercises) in textbook that are explicitly linked to fraud or ethics.

**** = 'Ethics' and 'Ethical issues' in index (number of sections/topics referred to).

***** $=$ 'Fraud', 'Manipulation' and 'Theft' in index (number of sections/topics referred to).

****** $=$ Number of pages dedicated to fraud or ethics and MA, excluding cases and exercises. 
addressed without explicitly referring to the possibility of unethical behavior, this was also not identified as a section dealing with the 'ethical' aspects of MA. Such a section was rather interpreted as a 'technical' section, since it often included discussions about the potential 'technical' problems of an MA instrument, without questioning the underlying values or moral implications of such an MA instrument.

\section{Findings}

This section presents the summary reports of the analysis of the five MA textbooks, highlighting some of the most important findings to give an impression of the textbook's content and the extent to which ethical considerations were integrated.

\section{Anthony and Govindarajan: management control systems}

Anthony and Govindarajan's (2007) textbook does not include specific sections that deal with the ethics of MA, but at a few places references are made to possible unethical consequences of control systems. 'Fraud' itself is only mentioned a few times, for instance in the context of formal controls:

Various safeguards are built into the information processing system to ensure that the information flowing through the system is accurate, and to prevent (or at least minimize) fraud of every sort. (Anthony \& Govindarajan, 2007, p. 104)

Furthermore, one section in the textbook deals with human behavior in organizations and informal control, and points to the importance of 'culture' and 'management style' and their relation with MA (Anthony \& Govindarajan, 2007, pp. 98-103). The discussion of these factors, however, is very limited: although culture is seen as 'the most important internal factor' (Anthony \& Govindarajan, 2007, p. 100), its discussion is very general and limited to less than half a page, and issues such as the role of culture in triggering or rationalizing unethical behavior are not addressed. The chapter that introduces incentives and agency theory ends with statements from critics who say that agency theory 'vastly oversimplifies' and has assumptions that do not do justice to the 'real world'. This very small section (about half a page of text) reads as an 'afterthought' (Anthony \& Govindarajan, 2007, pp. 533-534) and is especially minimal when compared to the rest of the chapter. To illustrate this: the remarks about the limited applicability of the theory are not considered important enough to be included in the chapter summary. Explicit critical remarks about ethics, or questions addressing ethical considerations other than those questioning whether students would 'like' to work in a particular organizational culture with certain types of control systems - could not be identified in the exercises, main text and cases of this textbook.

\section{Horngren, Datar and Rajan: cost accounting: a managerial emphasis}

Horngren et al. (2015) open the fifteenth edition of their textbook by stating that 'Chapter 1 [...] includes more material on the importance of ethics, values, and behaviors' (Horngren et al., 2015, p. xvii). The introductory chapter and the chapter that discusses the levers- 
of-control indeed include a few remarks on fraud and the ethical consequences of control choices, for instance:

It's not unusual for managers to cut corners and misreport numbers to make their performance look better than it is, as happened at companies such as Enron [...] To prevent unethical and outright fraudulent behavior, companies need to balance the push for performance resulting from diagnostic control systems, the first of four levers of control, with three other levers: boundary systems, belief systems, and interactive control systems. (Horngren et al., 2015, p. 894)

Here, the link between an 'unbalanced' use of diagnostic control systems is connected to potential unethical problems or consequences. Furthermore, in most chapters one of the exercises explicitly addresses a question related to the 'ethical course of action'. To illustrate this, in a chapter on costs and pricing, after having provided students with information about a repair-or-buy decision, the textbook asks:

If Dickenson's objective is to maximize profits, which option would he recommend to Lowry?

What would be the ethical course of action? (Horngren et al., 2015, p. 546)

Although an ethical consideration is triggered, no further theory or framework is provided to guide the students when addressing this issue. In other words, it remains unclear what is meant with 'ethical course of action', although the 'ethical course of action' seems to imply a different choice than the 'profitable' course of action. Closest to a framework for assessing ethics is the code of conduct of the Institute of Management Accountants (Horngren et al., 2015, p. 18). The chapter about budgeting addresses some of the 'human' aspects of budgeting, such as the creation of budget slack and target stretching (Horngren et al., 2015, pp. 218-221).

\section{Merchant and Van der Stede: management control systems}

Merchant and Van der Stede's (2007) textbook acknowledges a deep relation between ethics and MA by stating that ethics can be used to question the very foundations of control systems, and for questioning the prioritization of profits before employee welfare. The textbook also adds, however, that such 'deep' questions are beyond the scope of the textbook (Merchant \& Van der Stede, 2007, p. 693). The textbook does assign a specific chapter to the topic of ethics that includes a - limited - introduction to some of the mainstream ethical theories such as utilitarianism, virtue ethics and ethics of duty. Furthermore, some of the textbook's cases can be used to trigger ethical considerations and reflect on the possible (adverse) effects of MA instruments (Merchant \& Van der Stede, 2007, pp. 685-720). Furthermore, the 'ethics chapter' identifies four control-related ethical issues that are dealt with in some detail: budgetary slack, earnings management, responding to flawed control indicators and using very tight control indicators. In addition, the same chapter proposes a six-step approach to analyzing an ethical issue (Merchant \& Van der Stede, 2007, pp. 691-692). One of the consequences of devoting a specific chapter to ethics is that some of the discussions of ethical problems of a specific MA instrument are detached from the introduction of the MA instrument itself. For instance, when performance-related 'myopia' is addressed, the book refers to the discussion in the 'ethical chapter', thus detaches the discussion of the ethical aspects from the main text in which the technique is introduced (Merchant \& Van der Stede, 
2007, p. 444). However, throughout the textbook, some discussions on the ethical aspects of MA are included, most notably in the chapter on the 'control system costs' that discusses the negative attitudes produced by controls, data manipulation and behavioral displacement problems (Merchant \& Van der Stede, 2007, pp. 179-217).

\section{Simons: performance measurement and control systems for implementing strategy}

Simons' (2000) textbook is somewhat different from the other MA textbooks because it specifically focuses on performance measurement and the operationalization of the levers-of-control framework. In the main text of the chapter on performance measurement, some possible effects of a diagnostic use of performance measures on unethical behavior (such as 'gaming' the system and creating slack) are discussed (Simons, 2000, pp. 212-215). The discussion of these unethical behaviors is situated in the context of what Simons calls 'tensions', in an effort not to simply disregard the diagnostic use of performance measures all together. Simons (2000) explains, for instance, that managers who mostly use performance measures in a diagnostic (as opposed to an interactive) manner may trigger dysfunctional behavior. The textbook explicitly discusses ethical issues related to the fraud triangle and other factors that may lead to unethical behavior (Simons, 2000, pp. 269-273). Furthermore, three different parts in the textbook deal with assumptions that underlie various theories in MA (see Table 1). The textbook contains a large number of cases, and three of them specifically address the failure of internal controls, unethical behavior and fraud. For example, one short case deals with the pressure derived from performance targets and the creation of false revenues (Simons, 2000, p. 272), while another case discusses in great detail how failing internal controls enabled the false reporting of profits (Simons, 2000, pp. 646-664).

\section{Zimmerman: accounting for decision making and control}

Zimmerman's (2003) textbook provides an introduction to various MA topics such as $\mathrm{ABC}$ costing, budgeting, transfer pricing and cost accounting, and underlying theories such as agency theory. In the introductory chapter, the book states that it assumes that 'individuals maximize their self-interest', and that this leads both in the for-profit and not-for-profit sector to 'similar conflicts' (Zimmerman, 2003, pp. 3-4). As the main reason to apply control, Zimmerman (2003, p. 4) mentions 'to prevent fraud and embezzlement', which is in line with the textbook's assumption that human behavior is mostly motivated by self-interest. Zimmerman (2003) is explicit about the 'economical perspective' of the textbook, which is briefly contrasted to other perspectives and theories (Zimmerman, 2003, pp. 6, 158), such as different needs theories from psychology (Argyris, 1953; Maslow, 1943). Furthermore, regarding human behavior, adverse selection and moral hazard are discussed in some detail in the light of agency theory (Zimmerman, 2003, p. 162). However, the textbook treats adverse selection and moral hazard rather as qualities or side effects of agency problems rather than labeling them ethical issues. A similar point can be made about the sections that discuss the gaming of performance measures (Zimmerman, 2003, p. 170), the horizon problem (Zimmerman, 2003, pp. 160-161), and earnings management (Zimmerman, 2003, p. 179), which also 
examine negative (side) effects of MA instruments, explicitly addressing whether or how these behaviors can or should be considered 'unethical'. This textbook has one explicit reference to 'fraud' and 'embezzlement', in a paragraph in which internal controls (and the consequences of failing controls) are discussed. Furthermore, the textbook contains a few small cases and exercises that could be used to consider ethical aspects of MA. For instance, Zimmerman (2003, p. 185) briefly introduces McGregor's Theory X Theory $\mathrm{Y}$ in an exercise, and subsequently asks the reader to 'critically analyze Theory $\mathrm{X}$-Theory Y' - without explaining how to engage in such a critical analysis. Lastly, Zimmerman (2003) includes many exercises to practice the use and the technical qualities of MA instruments, but the analysis of the textbook did not yield many results regarding the integration of ethical reflections in the exercises, main text and cases.

\section{Discussion and suggestions}

\section{Discussion}

At least two observations can be made when comparing the different MA textbooks. First, on a more general note, most textbooks, the Merchant and Van der Stede (2007) textbook being an exception, do not strongly integrate ethical considerations of MA instruments and their effects. The analysis of the main texts pointed to the relatively limited extent to which the ethical aspect of MA was integrated in the textbooks, even though there were various opportunities to discuss moral implications of MA (e.g. regarding incentives that trigger certain types of behavior such as gaming or overproduction, international transfer prices that are set in such a way that developing countries hardly receive tax money, and unfair cost allocations). Sometimes, however, ethical considerations were integrated in an exercise, for instance, in Horngren et al. (2015) a question regarding the 'ethical course of action' was sometimes included - implicitly assuming that this course of action might be different from the technical (economically rational) course of action. Although this might be a promising way to trigger a consideration or discussion about the ethics of MA, more background in terms of ethical vocabulary and theory would probably enhance the depth of such a consideration or discussion. Also, clear teaching notes on how to guide a discussion about the ethics of MA should be provided to teachers to guide a possible discussion in a classroom.

Second, the content analysis revealed that ethical considerations are stronger integrated in the Merchant and Van der Stede (2007) textbook than in the other textbooks. A significant amount of the texts on ethics in this textbook are located in a specific chapter on ethics. Although this has as an advantage that many ethics-related issues are bundled and are easy to look up, this also may give rise to two risks: first, the chapter may not be discussed in MA courses when professors have to make a selection of the chapters of the book (for instance, because there is only limited time in a course or a maximum number of chapters a professor wants to include), and second, the chapter runs the risk of becoming an 'ethical island', separated from the 'technical' aspects of MA. Although the remarks in a separated chapter can be very valuable, as is the case in the Merchant and Van der Stede textbook, the choice not to integrate them in the main text alongside the technical aspects may weaken the potential of such ethical considerations. This point resembles Hopper's (2013, p. 128) observation that sometimes ethics-related initiatives 
may become 'isolated islands within courses with pedagogical philosophies at odds with critical contributions.' Furthermore, the textbook by Merchant and Van der Stede (2007) seems to be aimed at the intermediate or advanced level, i.e. it already requires a basic understanding of MA instruments, while the other textbooks are aimed at the introductory level. I think that including ethical considerations in textbook for more advanced courses is good, but that does not mean that introductory textbooks should not (also) include such ethical considerations. Furthermore, if first the technical aspects are presented to students (in an introductory textbook) and only the later (in an advanced textbook) the ethical considerations, this may result in another 'ethical island' effect: the ethical considerations run the risk of becoming detached or isolated from the MA instruments on which they reflect. This potentially turns such considerations into 'afterthoughts', which only happen after the technical aspects are discussed, impeding the integration of ethical considerations in MA education.

The question how MA textbooks, particularly those aimed at the introductory level, can further introduce ethical aspects alongside technical aspects thus still largely remains. In the following section I will sketch what a more integrated approach to MA education might look like.

\section{Suggestions for integrating ethical considerations in MA education}

In this section I would like to give three ${ }^{3}$ examples of how ethical considerations can be further integrated in MA education. Each of these three examples relates to a core part of MA that will probably be discussed in most introductory textbooks and courses on MA. The first example is about agency theory, the second example is about performance measurement and the third example is about international transfer pricing. A nuanced and balanced discussion of these topics, while paying attention to both the 'ethical aspects' and the 'technical aspects', has the potential to contribute to a better and broader understanding of the moral implications of MA instruments and their effects.

\section{Assumptions regarding human behavior in agency theory}

A topic that is probably addressed in all MA courses is agency theory, which in its most rudimentary form addresses the divergent interests of a principal and an agent (Jensen \& Meckling, 1976). The introduction of agency theory in an MA textbook or course provides a good context to discuss the assumptions regarding human behavior. As the content analysis shows, some MA textbooks already include a (brief) section on the underlying assumptions of some MA instruments (see also Table 1), however, this discussion can be extended by going beyond the 'obligatory' statement that 'there might be other assumptions or theories'. It seems appropriate to provide students with a more nuanced view of human behavior and the understanding that agency theory is just one theory to understand MA problems - among other theories. Furthermore, a discussion of the performativity thesis - i.e. the claim that models taught to students may effect the models they aim to describe - may enhance the student's awareness of the presence and potential of the underlying assumptions of economic theories and, consequently, the moral limits of models built on such assumptions (cf. Callon, 2007; Vosselman, 2014). 
The paper by Martynov (2009) can be helpful to introduce and discuss the underlying assumptions of agency theory and their connection with ethics. Martynov (2009, p. 240) specifically contrasts agency theory and stewardship theory:

the main assumption of agency theory is that of a self-serving, opportunistic manager, while the main assumption of stewardship theory is that of a pro-social, collectivist manager.

A discussion of underlying assumptions thus creates an opportunity to discuss 'alternative' theories that can be used to understand MA, such as stewardship theory - which assumes that employees are intrinsically motivated (Davis, Schoorman, \& Donaldson, 1997) - and self-determination theory - which assumes that employees are motivated by relatedness, autonomy and competence (Gagné \& Deci, 2005). These two theories are increasingly incorporated in research on MA, which forms an additional reason to include these theories in courses on MA (see also the recommendations by Murphy \& O'Connell, 2017). Empirical papers that can be used to discuss stewardship theory in an MA context are for instance Segal and Lehrer (2012) and Van der Kolk, Ter Bogt, and Van Veen-Dirks (2015), and papers that apply self-determination theory in an MA context are for instance Groen, Wouters, and Wilderom (2016) and De Baerdemaeker and Bruggeman (2015).

\section{International transfer pricing}

Another topic that is present in most MA courses is transfer pricing. Transfer pricing examines the price business unit A has to pay for a good or service from business unit $\mathrm{B}$. When business unit $\mathrm{A}$ is in a different geographical zone than business unit $\mathrm{B}$ - potentially with different taxation policies - this is called international transfer pricing. This domain of international transfer pricing has gained attention over the past years, as large multinationals such as Starbucks, Amazon and Google ${ }^{4}$ are under pressure to be transparent about their international transfer pricing constructions that seemed to be designed to 'optimize' the payable tax. A large gray area exists between what can be considered tax avoidance - which is considered legal - and tax evasion - which is considered illegal. Although the textbooks already discuss international transfer pricing and the possibilities this gives for lower taxes, ethical considerations of this issue are largely absent. Questions such as 'Is it fair to avoid paying taxes using smart transfer prices?' and 'What are potential consequences of the large-scale application of tax avoidance via international transfer pricing?' are not or hardly addressed. International transfer pricing provides a good opportunity to discuss or question whether it would be 'fair' to engage in these types of policies (see also the discussion by Sikka et al., 2007, pp. 13-14). Such a discussion could for instance be connected to different conceptions of 'fairness' or 'justice', such as those expressed by John Rawls (1971) in A Theory of Justice. Rawls' notions of procedural justice - i.e. whether fair procedures are in place - and distributive justice - i.e. whether rights or resources are fairly distributed - may be instrumental in critically examining the responsibilities of multinational organizations.

To integrate ethical considerations in discussions about international transfer pricing, the paper by Mehafdi (2000) about the ethics of international transfer pricing may also be helpful. This paper discusses in great detail the harm that some international transfer prices can do to different types of stakeholders. By, for instance, asking students to read the paper and reflect on it, or to connect the types of harm identified in the paper 
(physical, economic or psychological) to newspaper articles, awareness of the moral implications of international transfer pricing may be enhanced.

\section{Performance measurement}

Performance measurement is about the measurement of output, and is often used to facilitate decision-making or to incentivize those whose groups or individuals whose performance is measured. Interestingly, various textbooks on business ethics include cases that can be considered 'typical' MA cases about performance measurement. Such cases often highlight how performance measurement can trigger to unethical behavior, while MA textbooks not always take this opportunity to discuss the ethical dimension of performance measurement or its possible consequences. To give one example, the Ford Pinto case (Hoffman, 1982) is included in various textbooks on business ethics to demonstrate how strict performance measures may lead to the design of an unsafe car. In this case, a car was designed that had to meet a range of very strict targets regarding its production costs and weight. The car that was eventually designed did indeed 'hit' the targets, however, even minor rear-end collisions would cause the car's fuel tank to explode, which caused many deadly car fires. In a similar vein, the more recent Volkswagen emission scandal can also be seen in the light of a desire and pressure to 'hit' performance targets regarding carbon emissions. Although it is very useful that textbooks and courses on business ethics deal with this issue and discuss performance measurement's potential pitfalls, a discussion about it in a business ethics class also runs the risk of becoming an 'ethical island' - detached from the actual accounting topics it tries to scrutinize. This potentially results in students agreeing on what is the most 'optimal' (technical) performance measure during an MA course, while in a business ethics course the same students may (too quickly) agree on what the most 'ethical' course of action would be. By separating the technical discussion from the ethical discussion, both discussions fail to capture the difficulty of real life decisions, in which both the ethical and technical aspects are present at the same time.

Regarding the use of literature to guide discussions on the ethical aspects of performance measures, it might be interesting to turn to introductory texts about utilitarianism and its critiques (e.g. Bentham, 1789; Everett \& Tremblay, 2014; Mill, 1861; Rosanas \& Velilla, 2005). This stream in normative ethics is, like performance measurement, concerned with measuring outcomes (ends), and advocates making decisions that produce the maximum utility. The logic behind this stream of normative ethics is that 'the end justifies the means', which, similar to some performance measures, can be critiqued by stating that not all means are (or should be) allowed, and that it is therefore also important to examine the means that are used. For instance, even though the 'number of items sold' might be a good performance measure for the effectiveness of a sales person, this does not mean that everything (such as in extreme cases bribing or manipulating accounts) is allowed to 'hit' a performance target. Nevertheless, using performance measures in a very strict way could signal to employees in an organization that the 'end' is what matters (most), regardless of the means used to achieve that end. Discussions about performance measures in textbooks should therefore, I think, teach students that performance measures are powerful instruments that should be handled with care. A discussion of means and ends, perhaps in combination with other more critical texts about performance measurement (e.g. Cugueró-Escofet \& Rosanas, 2017; Kerr, 1975; Kerssens-Van 
Drongelen \& Fisscher, 2003; Ordóñez et al., 2009) could form a fruitful starting point for integrating ethical considerations when introducing performance measures in MA education.

\section{Conclusions}

This paper discusses the integration of ethical considerations in MA education and makes two contributions to the accounting education literature. First, this paper developed an argument based on MacIntyre (1981) proposing that MA instruments such as performance measurement are not morally neutral. Furthermore, it is proposed that students and teachers should be aware of the moral implications of MA instruments so that these implications can be recognized and discussed in MA education. Second, this paper extends the accounting education literature by presenting findings from a content analysis of top-ranked MA textbooks. The findings demonstrate that most MA textbooks only marginally touch upon ethical reflections in the main texts, cases and exercises, and that more can be done to facilitate ethical considerations, extending the body of research that critically examines the integration of ethics in accounting education (Amernic \& Craig, 2004; Boyce, 2004; Carmona, 2013; Chabrak \& Craig, 2013; Graham, 2012; Young \& Annisette, 2009). Specifically, the content analysis highlights that in cases in which students are asked to critically reflect on the ethical aspects of MA, little guidance or background information is offered to facilitate in-depth considerations or discussions on the moral values that underlie MA instruments and theories. Also, it is brought to the attention that having a separate section on ethics in an MA textbook or in a curriculum may yield positive effects, yet, such separate sections also risk becoming 'detached' from the remainder of the textbook or curriculum, which hurts the integration of ethical considerations in MA education.

A possible objection to integrating ethical considerations in introductory MA textbooks or courses might be that students first need to learn about the technical aspects of MA before they can critically reflect on their moral implications. Although I agree students indeed have to understand an issue in order to be able to reflect on it, I think that the current detachment of ethical considerations (if present) from the moment that MA instruments are first introduced is undesirable because this may lead students to think that the ethical consideration is merely an 'afterthought', rather than an essential part of the decision to use or not to use a particular MA instrument in a specific situation.

There are some limitations to this study, which also form possibilities for future research. First, this paper examined MA textbooks that are dominantly used in the socalled 'western world' (cf. Hoffjan \& Wömpener, 2006; Strauss \& Zecher, 2013), and a wider selection of MA textbooks, perhaps even categorized per region in which they are used, could make comparisons and produce findings that are more robust. The review included in this paper is intended as an illustration and a stepping stone for further research. Second, the three suggestions in this last part of this paper are far from being collectively exhausting. Future research may further develop these points and extend explore possibilities for integrating ethical considerations in MA education, using various theories and methods. This paper can also be seen as a call for more academic work at the intersection of MA and ethics. The paper argues that MA itself has an inherent ethical dimension to it, while this ethical dimension is still relatively underexplored in the 
literature, although there are interesting exceptions (e.g. Cugueró-Escofet \& Rosanas, 2017; Rosanas \& Velilla, 2005). Lastly, accounting education can be examined by focusing on a range of facets (e.g. the professors, the teaching material, the teaching methods, the curriculum), by using various research methods (e.g. surveys, interviews, case studies, document analysis), and by scrutinizing different subjects within accounting education (e.g. financial accounting, auditing, management control). It is evident that different research design choices may lead to different insights, and the presented findings should therefore be seen in the light of the limitation that this paper only analyzes textbooks in the field of MA, using a content analysis. I would like to encourage future research to complement the findings of this content analysis, for instance by focusing not on MA textbooks but on syllabi used in different universities worldwide, or by using questionnaires or interviews with MA educators to further examine what is already done and what can be improved in terms of integrating ethical considerations in MA education.

Merino (2006, p. 378) ended her historical analysis of accounting education and its critics by stating that she did not see 'changes happening anytime soon'. I would like to be slightly more optimistic by not only pointing to the work that has already been done in improving accounting education, but also by referring to the changing public debate. There is an increased awareness, also outside of the field of accounting, that education in the broader fields of economics and business has to change (cf. Nussbaum, 2010; Raworth, 2017). I sincerely hope this paper is instrumental in improving the integration of ethical considerations in MA education, and more specifically in MA textbooks. With more integrated ethical considerations, students, (future) managers and accountants will be better able to understand the moral implications of their work and make better decisions. Furthermore, such an enhanced awareness of the moral implications of MA can help to (re)establish accounting as a responsible academic discipline that is not only concerned with technics, but also with ethics.

\section{Notes}

1. Both Raworth (2017) and Sedláček (2011) argue that 'mainstream' economics is based on a wrong reduction of human behavior. The idea of the 'homo economicus' exagerates and overemphasizes the economic, rational, opportunistic and egoistic motivations of human behavior, while it underemphasizes or even ignores other motivations to act, such as compassion, love or altruism. Sedláček (2011) and Raworth (2017) trace back this overemphasis on the 'economic' side of human behavior to a selective reading of Adam Smith's (1759, 1776) works. Sedláček (2011, p. 210) therefore argues that a closer reading of Smith's work should result in the conclusion 'that moral questions must be included in economics'.

2. For the content analysis presented here, I use the editions mentioned in this sentence. My aim is not so much to compare these textbooks, but to get an impression of the extent to which ethical considerations are integrated in some important textbooks. I acknowledge that there might be differences between earlier and later editions of the referenced textbooks in terms of the attention they give to ethics.

3. The list of examples is not exhaustive and could be expanded with numerous other MA topics, but the aim of this paper is to provide a starting point and to illustrate how a stronger integration of ethical considerations in MA education can possibly be achieved.

4. See for instance Google, Amazon, Starbucks: The rise of 'tax shaming' www.bbc.com/news/ magazine-20560359, retrieved at 15 July 2017. 


\section{Acknowledgements}

The author would like to thank Salvador Carmona, Peter Kajüter and the two anonymous reviewers for their constructive feedback. An earlier version of this paper was presented at the 41st European Accounting Conference in Milan (2018). The author thanks the participants for their valuable feedback.

\section{Disclosure statement}

No potential conflict of interest was reported by the author.

\section{ORCID}

Berend van der Kolk (D) http://orcid.org/0000-0003-2011-4585

\section{References}

Amernic, J., \& Craig, R. (2004). Reform of accounting education in the post-Enron era: Moving accounting 'out of the shadows'. Abacus, 40(3), 342-378.

Anthony, R. N., \& Govindarajan, V. (2007). Management control systems. Boston, MA: McGraw-Hill.

Argyris, C. (1953). Human problems with budgets. Harvard Business Review, 31(1), 97-110.

Beabout, G. R. (2013). Macintyre against the manager BT. In G. R. Beabout (Ed.), The character of the manager: From office executive to wise steward (pp. 99-110). London: Palgrave Macmillan.

Bentham, J. (1789). The principles of morals and legislation. New York: Prometheus Books.

Boyce, G. (2004). Critical accounting education: Teaching and learning outside the circle. Critical Perspectives on Accounting, 15(4), 565-586.

Boyce, G. (2008). The social relevance of ethics education in a global(ising) era: From individual dilemmas to systemic crises. Critical Perspectives on Accounting, 19(2), 255-290.

Callon, M. (2007). What does it mean to say that economics is performative? In L. Mackenzie, D. Muniesa, \& F. Siu (Eds.), Do economists make markets? On the performativity of economics (pp. 311-357). Princeton, NJ: Princeton University Press.

Carmona, S. (2013). Accounting curriculum reform? The devil is in the detail. Critical Perspectives on Accounting, 24(2), 113-119.

Chabrak, N., \& Craig, R. (2013). Student imaginings, cognitive dissonance and critical thinking. Critical Perspectives on Accounting, 24(2), 91-104.

Cooper, D. J., Dacin, T., \& Palmer, D. (2013). Fraud in accounting, organizations and society: Extending the boundaries of research. Accounting, Organizations and Society, 38(6-7), 440457.

Cugueró-Escofet, N., \& Rosanas, J. M. (2017). The ethics of metrics: Overcoming the dysfunctional effects of performance measurements through justice. Journal of Business Ethics, 140(4), 615-631.

Davis, J. H., Schoorman, F. D., \& Donaldson, L. (1997). Toward a stewardship theory of management. Academy of Management Review, 22(1), 20-47.

de Baerdemaeker, J., \& Bruggeman, W. (2015). The impact of participation in strategic planning on managers' creation of budgetary slack: The mediating role of autonomous motivation and affective organisational commitment. Management Accounting Research, 29, 1-12.

Everett, J., \& Tremblay, M.-S. (2014). Ethics and internal audit: Moral will and moral skill in a heteronomous field. Critical Perspectives on Accounting, 25(3), 181-196.

Franco-Santos, M., Lucianetti, L., \& Bourne, M. (2012). Contemporary performance measurement systems: A review of their consequences and a framework for research. Management Accounting Research, 23(2), 79-119. 
Frey, B. S., Homberg, F., \& Osterloh, M. (2013). Organizational control systems and pay-for-performance in the public service. Organization Studies, 34(7), 949-972.

Gagné, M., \& Deci, E. L. (2005). Self-determination theory and work motivation. Journal of Organizational Behavior, 26(4), 331-362.

Graham, A. (2012). The teaching of ethics in undergraduate accounting programmes: The students' perspective. Accounting Education, 21(6), 599-613.

Groen, B. A. C., Wouters, M. J. F., \& Wilderom, C. P. M. (2016). Employee participation, performance metrics, and job performance: A survey study based on self-determination theory. Management Accounting Research, 36(1), 51-66.

Hoffjan, A., \& Wömpener, A. (2006). Comparative analysis of strategic management accounting in German- and English-language general management accounting textbooks. Schmalenbach Business Review, 58(3), 234-258.

Hoffman, W. M. (1982). Case study - The ford pinto. In W. M. Hoffman \& R. E. Frederick (Eds.), Corporate obligations and responsibilities: Everything old is new again (pp. 222-229). New York: McGraw-Hill.

Hopper, T. (2013). Making accounting degrees fit for a university. Critical Perspectives on Accounting, 24(2), 127-135.

Hopper, T., Storey, J., \& Willmott, H. (1987). Accounting for accounting: Towards the development of a dialectical view. Accounting, Organizations and Society, 12(5), 437-456.

Horngren, C. T., Datar, S. M., \& Rajan, M. V. (2015). Cost accounting: A managerial emphasis (15th ed.). Upper Saddle River, NJ: Prentice Hall.

Jensen, M. C., \& Meckling, W. H. (1976). Theory of the firm: Managerial behavior, agency costs and ownership structure. Journal of Financial Economics, 3(4), 305-360.

Kaidonis, M. A. (2004). Teaching and learning critical accounting using media texts as reflexive devices: Conditions for transformative action or reinforcing the status quo? Critical Perspectives on Accounting, 15(4-5), 667-673.

Kerr, S. (1975). On the folly of rewarding A, while hoping for B. Academy of Management Journal, 18(4), 769-783.

Kerssens-van Drongelen, I. C., \& Fisscher, O. A. M. (2003). Ethical dilemmas in performance measurement. Journal of Business Ethics, 45(1), 51-63.

Krippendorff, K. (1989). Content analysis. In E. Barnouw, G. Gerbner, W. Schramm, T. L. Worth, \& L. Gross (Eds.), International encyclopedia of communication (pp. 403-407). New York: Oxford University Press.

MacIntyre, A. (1981). After virtue. New York: Bloomsbury Academic.

Martynov, A. (2009). Agents or stewards? Linking managerial behavior and moral development. Journal of Business Ethics, 90(2), 239-249.

Maslow, A. H. (1943). A theory of human motivation. Psychological Review, 50(4), 370-396.

Mehafdi, M. (2000). The ethics of international transfer pricing. Journal of Business Ethics, 28(4), 365-381.

Merchant, K. A., \& van der Stede, W. A. (2007). Management control systems (2nd ed.). Edinburgh Gate, England: Pearson Education.

Merino, B. D. (2006). Financial scandals: Another clarion call for educational reform-A historical perspective. Issues in Accounting Education, 21(4), 363-381.

Mill, J. S. (1861). Utilitarianism. Indianapolis, IN: Hackett Publishing Company.

Murphy, T., \& O'Connell, V. (2017). Challenging the dominance of formalism in accounting education: An analysis of the potential of stewardship in light of the evolution of legal education. Critical Perspectives on Accounting, 44, 1-29.

Nussbaum, M. C. (2010). Not for profit: Why democracy needs the humanities. Princeton, NJ: Princeton University Press.

Ordóñez, L., Schweitzer, M., Galinsky, A., \& Bazerman, M. (2009). Goals gone wild: The systematic side effects of overprescribing goal setting. Academy of Management Perspectives, 23(1), 6-16.

Rawls, J. (1971). A theory of justice. Boston, MA: Harvard University Press.

Raworth, K. (2017). Doughnut economics: Seven ways to think like a 21st-century economist. London: Random House Business Books. 
Rosanas, J., \& Velilla, M. (2005). The ethics of management control systems: Developing technical and moral values. Journal of Business Ethics, 57(1), 83-96.

Saravanamuthu, K., \& Tinker, T. (2002). The university in the new corporate world. Critical Perspectives on Accounting, 13(5), 545-554.

Saravanamuthu, K., \& Tinker, T. (2008). Ethics in education: The Chinese learner and post-Enron ethics. Critical Perspectives on Accounting, 19(2), 129-137.

Sedláček, T. (2011). Economics of good and evil: The quest for economic meaning from Gilgamesh to Wall Street. Oxford: Oxford University Press.

Segal, L., \& Lehrer, M. (2012). The institutionalization of stewardship: Theory, propositions, and insights from change in the Edmonton public schools. Organization Studies, 33(2), 169-201.

Sikka, P., Haslam, C., Kyriacou, O., \& Agrizzi, D. (2007). Professionalizing claims and the state of UK professional accounting education: Some evidence. Accounting Education, 16(1), 3-21.

Simons, R. (2000). Performance measurement \& control systems for implementing strategy. Upper Saddle River, NJ: Prentice Hall.

Smith, A. (1759). The theory of moral sentiments. New York: Prometheus books.

Smith, A. (1776). An inquiry into the nature and causes of the wealth of nations (1994 edition). New York: Modern Library.

Strauss, E., \& Zecher, C. (2013). Management control systems: A review. Journal of Management Control, 23(4), 233-268.

van der Kolk, B., ter Bogt, H. J., \& van Veen-Dirks, P. M. G. (2015). Constraining and facilitating management control in times of austerity: Case studies in four municipal departments. Accounting, Auditing \& Accountability Journal, 28(6), 934-965.

Vosselman, E. (2014). The 'performativity thesis' and its critics: Towards a relational ontology of management accounting. Accounting and Business Research, 44(2), 181-203.

Young, J. J., \& Annisette, M. (2009). Cultivating imagination: Ethics, education and literature. Critical Perspectives on Accounting, 20(1), 93-109.

Zimmerman, J. L. (2003). Accounting for decision making and control (4th ed.). Singapore: McGraw-Hill. 